\title{
Bacteriological monitoring of unheated human milk
}

\author{
D. C. DAVIDSON, R. A. POLL, AND C. ROBERTS \\ Special Care Baby Unit, and Regional Public Health Laboratory, Fazakerley Hospital, Liverpool
}

SUMMARY To assess the bacteriological quality of unpooled expressed breast milk, a pilot bottle sample of each donation was examined before the milk was given to the neonate. Provided the milk did not contain $>2500$ organisms $/ \mathrm{ml}$ or potential pathogens it was used unheated. Milk containing between 2500 and 5000 organisms $/ \mathrm{ml}$ and no potential pathogens was used after pasteurisation. Using these criteria, $67 \%$ of 460 donations were acceptable. However, because the bacteriological quality varied, $45 \%$ of domiciliary donations were discarded compared with only $29 \%$ of those from hospital.

Breast milk composition differs from cows' milk and artificial formulae in many important aspects. Some of these were described in the report from the Department of Health and Social Security (1974) which recommended that breast feeding should be encouraged. While human milk is generally accepted as ideal nutrition for term neonates, the composition varies and may not represent optimal nutrition for preterm infants and those of low birthweight. Davies (1977) showed that such infants fed artificial formulae had better rates of growth than those fed expressed breast milk. Nevertheless the importance of human milk to the young infant derives not only from its nutrient content but also from its 'antiinfective' properties. Lactoferrin, an iron-binding protein, is important in the prevention of infection by Escherichia coli; $\mathbf{B}_{12}$ and folate-binding proteins which limit the availability of these vitamins for bacterial growth are also important. Specific IgA immunoglobulin acts in the neonatal gut and limits the growth and reproduction of bacterial and viral pathogens. Maternal antibodies, cellular content, bacteriostatic enzymes, lysozyme, and nonpathogenic bacteria further contribute to the anti-infective properties of human milk.

Carefully controlled pasteurisation reduces the damage to the humoral components of human milk, whereas higher temperatures not only destroy vegetative bacteria but can adversely affect the anti-infective properties and alter the chemical composition of the milk (Ford et al., 1977; Williamson et al., 1978).

Fazakerley Hospital, Liverpool

Special Care Baby Unit

D. C. DAVIDSON, consultant paediatrician

Regional Public Health Laboratory

R. A. POLL, senior medical laboratory scientific officer C. ROBERTS, consultant microbiologist
In 1976 it was decided to examine the possibility of providing unheated, unpooled human expressed breast milk at this hospital for the nutrition of low birthweight babies, especially neonates in the intensive care unit, provided the bacteriological quality met our standards. Our experience of the bacteriological monitoring and provision of raw human milk is described.

\section{Materials and methods}

Only mothers who were free of communicable disease (for example, tuberculosis, respiratory infection, enteric, skin, or breast infection) and those not on drugs transmissible via breast milk were accepted as donors.

During a 2-year period (1976-78) samples of expressed breast milk (EBM) from hospital and from women at home were examined. All mothers received instruction on breast and hand hygiene and on the technique of manual expression of the breast, although most hospital specimens were obtained by the breast pump. After the EBM had been collected into autoclaved $100 \mathrm{ml}$ glass bottles, approximately $2 \mathrm{ml}$ milk was decanted into a sterile pilot bottle for bacteriological screening (Fig. 1). Those specimens collected in hospital were deep frozen to $-20^{\circ} \mathrm{C}$ in the breast milk bank freezer as quickly as possible, often within a few minutes of collection. Specimens from home were stored in the ordinary compartment of the domestic refrigerator (not deep frozen) and taken to the breast milk bank in an insulated cool box every 48 hours by the donors themselves or by domiciliary midwives. On receipt at the hospital milk bank these domiciliary donations were then also stored at $-20^{\circ} \mathrm{C}$. Each bottle was stored separately and not pooled before freezing. Donations varied in volume between 50 and $100 \mathrm{ml}$ 


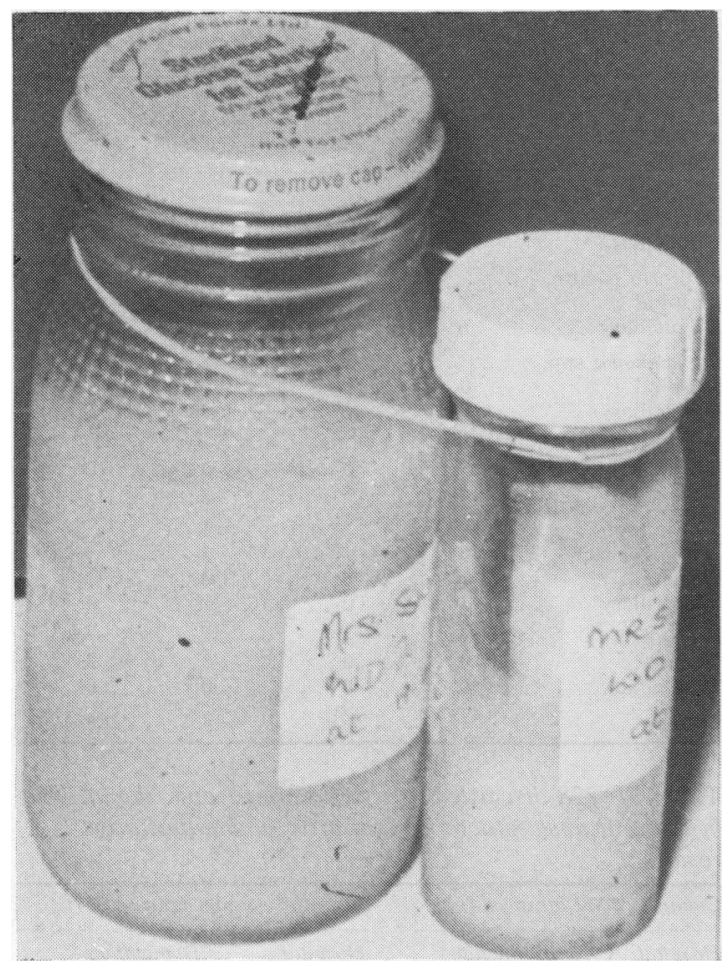

Fig. 1 Expressed breast milk donation with accompanying pilot bottle sample.

and did not remain in the bank for more than a few days because of the demand for human milk. Before milk was issued, the pilot bottle was removed, allowed to thaw at room temperature, and then bacteriologically screened. This usually took less than 24 hours and no raw specimen of breast milk was used until bacteriologically acceptable. When clearance was given the donation was allowed to thaw at room temperature and issued for feeding. Thawed specimens were stored in the domestic compartment of the refrigerator in the intensive care unit until needed. Any thawed specimen not used after 12 hours (although rare) was discarded to reduce risk of bacterial contamination and denaturation.

The pilot bottle of milk was examined soon after receipt in the laboratory. Total quantitative bacterial counts on unheated samples were performed in duplicate using 10 drops from a standard 50-dropper pipette on a 1 in 5 dilution of milk in 1 in 4 strength Ringer's solution, whereas pasteurised milk was examined undiluted to increase the chance of isolating organisms which would be present in smaller numbers than in unpasteurised milk. In both instances, the milk was inoculated on to $10 \%$ horse blood agar, MacConkey agar, $0.03 \%$ cetrimide agar, and nutrient agar containing $8.5 \%$ sodium chloride to facilitate the screening of organisms potentially detrimental to the safe use of milk. The sensitivity of the quantitative method meant that the minimum bacterial count detectable in unheated milk was 25 organisms $/ \mathrm{ml}$ and in pasteurised milk it was 5 organisms $/ \mathrm{ml}$. Arbitrary criteria applied to the EBM samples were: (1) Milk with a quantitative count of $<2500$ organisms $/ \mathrm{ml}$ (Wright, 1947) (consisting of, for example, micrococci, Staphylococcus albus, 'viridans type' streptococci, or diphtheroids which were considered to be contaminants probably derived from skin flora but unlikely to be pathogenic) was used unheated. (2) No donation was used unheated or pasteurised if the pilot bottle gave either a total count $>5000$ organisms $/ \mathrm{ml}$ or any detectable potential pathogen. On an arbitrary basis the potential pathogens were defined as Staphylococcus aureus, $\beta$-haemolytic streptococci, Pseudomonas spp., Proteus spp., Streptococcus faecalis, and any other organism from a potential enteric or water-borne source (here defined as 'coliforms' for convenience). (3) No donated milk with a total bacterial count of 2500-5000 organisms $/ \mathrm{ml}$ was used unheated. If the pilot sample had a bacterial count in this range, but none of the organisms listed in (2), the donated milk was pasteurised at $63^{\circ} \mathrm{C}$ for 30 minutes in a water bath and subjected to the same bacteriological screen, plus the alkaline phosphatase test. (Alkaline phosphatase is destroyed by a temperature of $63^{\circ} \mathrm{C}$ within 30 minutes and is used as evidence of adequate pasteurisation of cows' milk). Provided effective pasteurisation was established by no detectable growth on culture and a satisfactory phosphatase test, the milk was issued for use.

\section{Results}

The overall distribution of the bacterial counts of the EBM over the 2-year period is shown in Fig. 2. Clearly most EBM samples had low counts and the distribution shows gradually diminishing numbers of specimens up to 36000 organisms $/ \mathrm{ml}$. Although there were $33(4.5 \%)$ specimens with counts $>50000$ organisms $/ \mathrm{ml}$, most $(95 \cdot 3 \%)$ specimens gave counts of $<25000$ organisms $/ \mathrm{ml}$. A pilot investigation of anaerobic culture gave no additional information and was therefore stopped.

Of 688 raw EBM samples examined during the period, $513(75 \%)$ came from hospital and $175(25 \%)$ were domiciliary donations (Table 1). Within the three ranges of bacterial counts the figures for hospital and domiciliary isolates were similar--that is $460(67 \%)$ of EBM samples gave counts of 


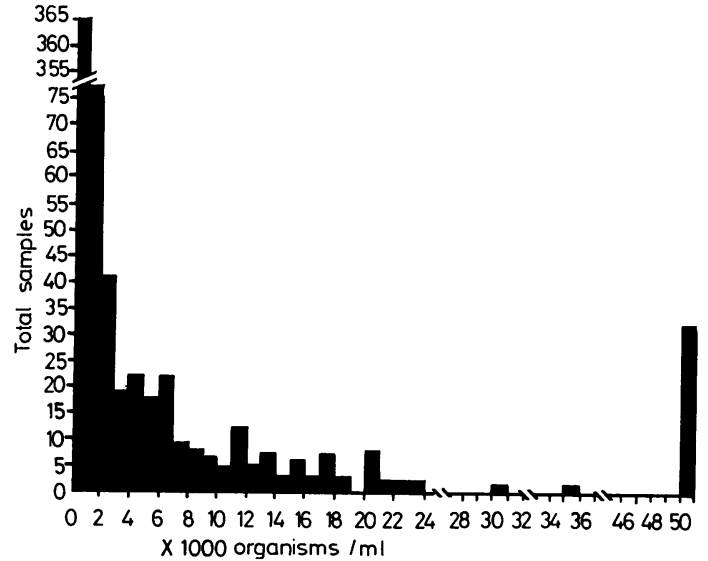

Fig. 2 Distribution of bacterial counts in expressed breast milk over a 2-year period (1 May 1976- 30 April 1978.

Table 1 Pattern of bacterial counts among hospital and domiciliary donations of expressed breast milk

\begin{tabular}{lllll}
\hline Source & \multicolumn{4}{l}{ Bacterial count $/ \mathrm{ml}$} \\
\cline { 2 - 5 } & $<2500$ & $2500-5000$ & $>5000$ & Total \\
\hline Hospital & $343(67)$ & $51(10)$ & $119(23)$ & 513 \\
Domiciliary & $117(67)$ & $15(8 \cdot 5)$ & $43(24 \cdot 5)$ & 175 \\
Totals & 460 & 66 & 162 & 688 \\
\hline
\end{tabular}

Percentages are given in parentheses.

$<2500$ organisms $/ \mathrm{ml}$, and $66(9 \cdot 6 \%)$ specimens gave counts of $2500-5000$ organisms $/ \mathrm{ml}$ and were pasteurised if no pathogen was present. Overall 162 $(24 \%)$ were immediately discarded without pasteurisation because of counts $>5000$ organisms $/ \mathrm{ml}$. Therefore, 526 (76\%) EBM specimens had acceptable quantitative bacterial counts, but some of these had potential pathogens. The main pathogens isolated were $S$. aureus and 'coliforms', but there was a difference in the total number of isolates and in the type of organism from home and hospital donations. Altogether $49(9 \cdot 6 \%)$ of 513 donations from hospital were discarded, compared with $60(34 \%)$ of 175 from homes. S. aureus was isolated from $23(4.5 \%)$ of hospital donations and from $5(3 \%)$ of home donations, whereas 'coliforms' were isolated from $21(4 \cdot 1 \%)$ of hospital and from $32(18 \%)$ of domiciliary collections. There was no particular relationship between quantitative counts and potential pathogens, and overall the pathogens were distributed throughout the three quantitative ranges (Table 2).

Of the EBM donations with counts in the ranges of $<2500$ and $2500-5000$ organisms $/ \mathrm{ml}, 51(7 \cdot 4 \%)$ and $15(2 \cdot 2 \%)$ of them respectively had potential pathogens and were discarded without further
Table 2 Potential pathogens isolated from expressed breast milk samples

\begin{tabular}{|c|c|c|c|c|}
\hline \multirow[t]{2}{*}{ Organism and source } & \multicolumn{4}{|c|}{ Bacterial count $/ \mathrm{ml}$} \\
\hline & $<2500$ & $2500-5000$ & $>5000$ & Total \\
\hline $\begin{array}{l}\text { S. aureus } \\
\text { Hospital } \\
\text { Domiciliary }\end{array}$ & $\begin{array}{r}15 \\
4\end{array}$ & $\begin{array}{l}5 \\
0\end{array}$ & $\begin{array}{l}3 \\
1\end{array}$ & $\begin{array}{r}23 \\
5\end{array}$ \\
\hline $\begin{array}{l}\text { Coliform bacilli } \\
\text { Hospital } \\
\text { Domiciliary }\end{array}$ & $\begin{array}{l}8 \\
6\end{array}$ & $\begin{array}{l}2 \\
5\end{array}$ & $\begin{array}{l}11 \\
21\end{array}$ & $\begin{array}{l}21 \\
32\end{array}$ \\
\hline $\begin{array}{l}\text { Pseudomonas spp. } \\
\text { Hospital } \\
\text { Domiciliary }\end{array}$ & $\begin{array}{l}0 \\
0\end{array}$ & $\begin{array}{l}0 \\
0\end{array}$ & $\begin{array}{l}1 \\
0\end{array}$ & $\begin{array}{l}1 \\
0\end{array}$ \\
\hline $\begin{array}{l}\text { Faecal streptococci } \\
\text { Hospital } \\
\text { Domiciliary }\end{array}$ & $\begin{array}{r}0 \\
14\end{array}$ & $\begin{array}{l}0 \\
3\end{array}$ & $\begin{array}{l}0 \\
2\end{array}$ & $\begin{array}{r}0 \\
19\end{array}$ \\
\hline $\begin{array}{l}\text { B-haemolytic } \\
\text { streptococci } \\
\text { Hospital } \\
\text { Domiciliary }\end{array}$ & $\begin{array}{l}1 \\
3\end{array}$ & $\begin{array}{l}0 \\
0\end{array}$ & $\begin{array}{l}0 \\
1\end{array}$ & $\begin{array}{l}1 \\
4\end{array}$ \\
\hline $\begin{array}{l}\text { Proteus spp. } \\
\text { Hospital } \\
\text { Domiciliary }\end{array}$ & $\begin{array}{l}0 \\
0\end{array}$ & $\begin{array}{l}0 \\
0\end{array}$ & $\begin{array}{l}3 \\
0\end{array}$ & $\begin{array}{l}3 \\
0\end{array}$ \\
\hline Totals & 51 & 15 & 43 & 109 \\
\hline
\end{tabular}

Table 3228 discarded expressed breast milk donations because of unsatisfactory qualitative and quantitative results

\begin{tabular}{lllll}
\hline \multicolumn{2}{ll}{ Counts $>5000 / m l(n=162)^{*}$} & & \multicolumn{2}{l}{ Potential pathogens $(n=66)^{*}$} \\
\cline { 1 - 1 } \cline { 5 - 6 } Hospital & Domiciliary & & Hospital & Domiciliary \\
\hline 119 & 43 & 31 & 35
\end{tabular}

*Allowance has been made for 43 specimens discarded which had excessive counts and potential pathogens.

processing. Another $43(6 \cdot 3 \%)$ were discarded because they had excessive bacterial counts and potential pathogens.

The total number of EBM donations discarded because of excessive bacterial counts or the presence of potential pathogens was $228(33 \%)$ (Table 3$)$. The remaining $460(66 \%)$ were acceptable because they contained no potential pathogen or excessive bacterial counts, as defined above, within the technical limitations of the methods employed.

\section{Discussion}

Like others, we experience difficulties in deciding what bacteriological criteria should be adopted to make EBM donations safe to give to neonates. We adopted arbitrary criteria based on such information as we could obtain. There appeared to be no widely agreed standards on the quantitative and qualitative content of human breast milk and no universally adopted figure for acceptable bacterial quality of EBM. There are no general guidelines on what are considered to be potential pathogens and the likely numbers of such species which are considered 
harmful to neonates. There are opposing views on the benefits conferred on babies fed raw or pasteurised milk as well as conflicting results on babies fed artificial milk as opposed to EBM.

Nevertheless we decided to investigate the quantitative and qualitative bacteriology of EBM submitted to our maternity unit. It is not possible to give precise ranges of acceptable counts or to investigate which organisms constitute an unacceptable hazard to neonates, particularly those undergoing intensive care. The criteria we adopted, although arbitrary, were necessarily stringent in order to protect our neonates from any hazard of milk-borne bacterial disease. Even with these strict criteria we were still able to issue $67 \%$ of donated EBM, a figure similar to that of Williamson et al. (1978). Overall only $29 \%$ (150 of 513) of hospital donations were discarded compared with $45 \%$ ( 78 of $175)$ of domiliciary collections because their bacteriological quality was either quantitatively or qualitatively unacceptable. We feel that probably the collection procedure of the domiciliary EBM was the main cause for $45 \%$ of samples being unacceptable. If the donation was unsatisfactory the donor was again visited and given further advice about hygiene by the domiciliary midwife. To some extent this was done in the case of unsatisfactory hospital donations but an additional factor was the inadequate cleaning of the breast pump and related equipment. This defect was also noted by Liebhaber et al. (1978) who recommended manual expression of milk, thereby reducing the need for pasteurisation. Our figures also reflect the difference caused by lack of supervision of domicilary collections, and if a neonatal unit relies heavily on domiciliary donations, closer supervision is necessary or it may be advisable to pasteurise all domiciliary donations. We should stress that our policy was devised to control the quality of the EBM and the whole procedure of collection, storage, etc. up to the time of feeding the neonate. The use of the pilot bottle provided us with a representative sample of EBM. We feel that if the donations had been pooled, even after being bacteriologically cleared, it would have added another factor to the procedure, with its attendant risks.

We did not attempt to assess the immunological or the nutritional benefits of using unpooled, unheated EBM, but we did try to assess clinically whether there was any hazard of infection. Clearly this is arbitrary, but we did not detect evidence of infection due to any of the organisms considered above in any baby fed EBM. We believe this was because EBM with potential pathogens was not used and also because EBM containing by definition nonpathogens $<2500$ organisms $/ \mathrm{ml}$ does not expose the baby to any risk. In fairness it should be said that if any baby is ill because of infection by an alleged nonpathogen (referred to earlier), it is extremely doubtful if the source of these ubiquitous organisms could be identified since they do not have a generally reliable marker system.

As a result of our experience in collecting and monitoring EBM, we have decided to continue to rely on raw EBM by fostering good hygiene technique which in most specimens yields low bacterial counts (Fig. 2). As a further safeguard, bacterial monitoring will exclude any donation of unsatisfactory quality. The development of this policy resulting from the ever pressing demand in our neonatal unit for EBM has led us to review our criteria in the light of these results and of other published work. We have considered the possibility of relaxing the quantitative criteria alone so that donations with higher bacterial counts (that is, those with $>\mathbf{2 5 0 0}$ organisms $/ \mathrm{ml}$ ) but no potential pathogens could be safely used. There is currently no generally agreed upper quantitative limit of likely nonpathogens, although most workers agree that it is inadvisable to use EBM containing potential pathogens. Ikonan and Maki (1977) used donations with counts $<20000$ organisms $/ \mathrm{ml}$ (some after heating) and discarded only $5 \%$ of all donations. If we had applied these criteria to our results in Fig. 2 we would have discarded only $10 \%$ of EBM donations on a quantitative basis alone. We are unwilling to accept EBM donations containing potential pathogens as we feel these could present unnecessary hazards to a vulnerable group of babies, particularly those undergoing intensive care. Milk containing bacteria which may be derived from a faecal origin is clearly unacceptable and these markers are used to exclude the possibility of contamination by enteric bacteria and viruses.

Breast feeding by a mother of her own normal baby will expose that baby to his own mother's bacterial flora which quantitatively may be $>2500$ organisms $/ \mathrm{ml}$, some of which may be potentially pathogenic. It is believed by some that these are probably less hazardous than the organisms from an unrelated milk donor, because a mother secretes antibodies in her milk which reflect her own immunological experience (Gunther, 1978).

As a result of the renewed interest in breast feeding and breast milk banks, attention has been given to the advantages and disadvantages of processing EBM. Because of the fear of contaminating EBM, attention has been directed to measures which provide a bacteriologically safe milk which still retains its immunological properties (British Medical Journal, 1977). However enterotoxins produced by certain bacteria-for example, $S$. aureus have caused outbreaks of food poisoning due to contaminated cows' milk (Wilson and Miles, 
1975) - and since the enterotoxin is to some extent heat resistant it is theoretically possible that even pasteurised human milk, although free from bacteria, may contain enterotoxin.

In addition, because the alkaline phosphatase of human milk is 40 times lower than cows' milk (Heyndrickx, 1962) the phosphatase test as applied to the latter may not be sufficiently sensitive as an indicator of adequate pasteurisation of EBM. Therefore, although rigidly controlled conditions safeguard the pasteurisation process, bacteriological quality control criteria can provide a final check of effective pasteurisation.

Milk rendered safe by boiling or even by carefully controlled pasteurisation appears to reduce levels of immunoglobulin, lactoferrin, lysozyme, and complement C3 factor (Ford et al., 1977; Evans et al., 1978), as well as certain nutrients (Williamson et al., 1978), although Raptopoulou-Gigi et al. (1977) in Edinburgh found that pasteurisation did not materially alter levels of IgA or lactoferrin. Total lymphocyte counts were also significantly decreased after pasteurisation (Liebhaber et al., 1977). These findings indicate the reduction of anti-infective properties of EBM with pasteurisation, and by avoiding this procedure we feel that unheated EBM of acceptable bacteriological standard provides a practical alternative for a baby in place of its own mother's milk. However, in spite of the advantages of the immunological content of nonpasteurised EBM we agree with Lucas et al. (1978) that it cannot be recommended for all special care baby units unless there are certain quality control safeguards.

Milk macrophages tend to adhere to the walls of the glass container and therefore simple storage may reduce the lymphocyte content. Moreover, Pitt (1976) suggested that freezing of milk will markedly diminish the number of viable cells and it must be admitted that either of these factors could have reduced the effective immunological value to our babies. Quantitative examination of the noncellular components of milk deep-frozen for 3 months at $-20^{\circ} \mathrm{C}$ had no appreciable effect on levels of lactoferrin, lysozyme, IgG, IgA, or C3 complement component (Evans et al., 1978). Repeated freezing and thawing would be expected to lead to reduction of these levels because of denaturation, but in our milk bank the process only happens once.

While cellular transfer in the breast milk from the natural mother may confer immunological advantages to her baby, it may be potentially harmful in an unrelated baby. Beer and Billingham (1975) reported a wasting syndrome similar to a graft $v$. host disease when neonatal rats were fed on the milk of an unrelated rat. Further work is needed to find out if this observation is important to human studies on unheated EBM.

We thank Professor Rosalinde Hurley of Queen Charlotte's Hospital for her help, the hospital and district midwives for their assistance, and Ms Angela Parry for clerical assistance.

\section{References}

Beer, A. E., and Billingham, R. E. (1975). Immunologic benefits and hazards of milk in maternal-perinatal relationship. Annals of Internal Medicine, 83, 865-871.

British Medical Journal (1977). Editorial: Heating human milk. British Medical Journal, 1, 1372.

Davies, D. P. (1977). Adequacy of expressed breast milk for early growth of preterm infants. Archives of Disease in Childhood, 52, 296-301.

Department of Health and Social Security (1974). Present Day Practice in Infant Feeding. Report on Health and Social Subjects No. 9. HMSO: London.

Evans, T. J., Ryley, H. C., Neale, L. M., Dodge, J. A., and Lewarne, V. M. (1978). Effect of storage and heat on antimicrobial proteins in human milk. Archives of Disease in Childhood, 53, 239-241.

Ford, J. E., Law, B. A., Marshall, M. E., and Reiter, B. (1977). Influence of the heat treatment of human milk on some of its protective constituents. Journal of Pediatrics, 90, 29-35.

Gunther, M. (1978). Cited by E. M. Widdowson in a report on a symposium on the protective properties of human milk. Archives of Disease in Childhood, 53, 684-686.

Heyndrickx, G. V. (1962). Investigations on the enzymes in human milk. Annales paediatrici, 198, 356-362.

Ikonan, R. S., and Maki, K. (1977). Letter: Heating human milk. British Medical Journal, 2, 386-387.

Liebhaber, M., Lewiston, N. J., Asquith, M. T., Olds-Arroyo, L., and Sunshine, P. (1977). Alterations of lymphocytes and of antibody content of human milk after processing. Journal of Pediatrics, 91, 897-900.

Liebhaber, M., Lewiston, N. J., Asquith, M. T., and Sunshine, P. (1978). Comparison of bacterial contamination with two methods of human milk collection. Journal of Pediatrics, 92, 236-237.

Lucas, A., Goddard, P., and Baum, J. D. (1978). Letter: Raw or pasteurised human milk? British Medical Journal, 1,781 .

Pitt, J. (1976). Breast milk leukocytes. Pediatrics, 58, 769-770.

Raptopoulou-Gigi, M., Marwick, K., and McClelland, D. B. L. (1977). Antimicrobial proteins in sterilised human milk. British Medical Journal, 1, 12-14.

Williamson, S., Finucane, E., Ellis, H., and Gamsu, H. R. (1978). Effect of heat treatment of human milk on absorption of nitrogen, fat, sodium, calcium, and phosphorous by preterm infants. Archives of Disease in Childhood, 53, 555-563.

Wilson, G. S., and Miles, A. A., editors (1975). Topley and Wilson's Principles of Bacteriology, Virology, and Immunity, sixth edition. Arnold: London.

Wright, J. (1947). Bacteriology of the collection and preservation of human milk. Lancet, 2, 121-124.

Correspondence to Dr C. Roberts, Regional Public Health Laboratory, Fazakerley Hospital, Lower Lane, Liverpool L9 7AL.

Received 15 March 1979 